\title{
Analisis Mineralogi dan Kandungan Kimia Endapan Lumpur Sidoarjo dan Arah Pemanfaatannya
}

\author{
Tri Winarno*, Jenian Marin, Yeremia B. A. Gunawan \\ Departemen Teknik Geologi Fakultas Teknik, Universitas Diponegoro, \\ Jl. Prof. Soedarto, SH, Kampus UNDIPTembalang, Semarang, Indonesia 50275
}

\begin{abstract}
Abstrak
Semburan lumpur Sidoarjo mengeluarkan volume sebesar $\pm 80.000 \mathrm{~m}^{3}$ setiap hari dan hanya dapat diatasi $\pm 60.000 \mathrm{~m}^{3}$ dengan cara mengalirkannya ke laut melalui Kali Porong. Surplus endapan lumpur tersebut meluap dan menggenangi daerah di sekitar pusat semburan lumpur sehingga menimbulkan masalah. Artikel ini memuat analisis mineralogi dan kandungan kimia dari endapan lumpur Sidoarjo sehingga dapat dimanfaatkan sesuai karakteristiknya. Sampel lumpur dinalisa menggunakan metode X-Ray Diffraction (XRD) dan X-Ray Fluorescence (XRF) untuk mengetahui mineralogi dan kandungan kimianya. Genesis dari endapan Lumpur Sidoarjo diinterpretasikan berasal dari batuan sedimen vulkaniklastik Formasi Kalibeng Atas yang bercampur dengan endapan Aluvial (Qa) karena mineralmineral lempung yang dijumpai didominasi oleh mineral montmorillonit. Keberadaan Zona Sesar Watukosek yang memanjang dari Kompleks Gunungapi Arjuno-Welirang diinterpretasikan memberikan kontrol struktur terhadap pembentukan gunungapi lumpur Sidoarjo. Pemanfaatan endapan Lumpur Sidoarjo berdasarkan mineralogi dan kandungan kimianya dikelompokkan menjadi lima bidang, yaitu kesehatan, pertanian, perikanan, industri, dan kosmetik. Setiap bidang pemanfaatan membutuhkan mineral-mineral lempung khusus sehingga endapan Lumpur Sidoarjo harus diolah terlebih dahulu untuk menghilangkan unsur pengotor, mineral berat, pengecilan ukuran, peningkatan kemampuan absorpsi, dan kapasitas tukar kation.
\end{abstract}

Kata kunci: Lumpur Sidoarjo; XRD; XRF; mineral lempung; pemanfaatan mineral lempung

\begin{abstract}
[Title: Characteristics of Clay Mineral of Sidoarjo Mud and Its Suggested Application at Renokenongo Village, Porong District, Sidoarjo Regency]Sidoarjo Mud Volcano still emits $\pm 80.000 \mathrm{~m}^{3}$ hot mud deposit per day and only $\pm 60.000 \mathrm{~m} 3$ of which is channeled into the ocean by Porong River. The surplus of the mud deposit overflowed and inundated the area around the center of the mudflow which have been making problems. This article deals with the mineralogy and chemical compound analysis of deposit Sidoarjo mud so that they can be directed to use in certain fileds, according to their characteristics. The samples were analyzed by X-Ray Diffraction Method (XRD) and X-Ray Fluorescence (XRF) method to determine the mineralogy and chemical composition. Sidoarjo Mud deposit genesis is interpreted from volcaniclastic sediment rock which come from Upper Kalibeng Formation because the clay minerals found by XRD analysis show that montmorillonite as dominant mineral. The Watukosek Fault zone which extend from Arjuno-Welirang volcanoes complex interpreted to give structural control over the formation of Sidoarjo mud volcano. Sidoarjo Mud deposit utilization based on the mineralogy and chemical composition can be divided into five sectors, e.g. health, agriculture, fishery, industry, and cosmetics. Each sector requires specific clay mineral which led to treatment toward the Sidoarjo Mud deposit in order to eliminate the impurities and non-clay mineral from the deposit and also to shrink the mineral size, absorption capability enhancement, and cation exchange capacity $(C E C)$ so the deposit can gain maximum utilization in each sector.
\end{abstract}

${ }^{*}$ Penulis Korespondensi.

Keywords: Sidoarjo Mud; XRD; XRF; clay mineral; clay mineral application

E-mail: triwingeo@gmail.com 


\section{TEKNIK, 40 (2), 2019, 92}

\section{Pendahuluan}

Semburan lumpur panas yang terjadi di lokasi pengeboran PT Lapindo Brantas, Desa Renokenongo, Kecamatan Porong, Indonesia sejak tahun 2006 menjadi salah satu bencana nasional yang terus berlanjut. Semburan Lumpur Sidoarjo ini telah mengakibatkan kerugian finansial maupun korban jiwa. Semburan ini mengeluarkan volume lumpur sebesar $\pm 80.000 \mathrm{~m}^{3}$ setiap hari dan hanya dapat diatasi $\pm 60.000 \mathrm{~m}^{3}$ dengan cara mengalirkannya ke laut melalui Kali Porong. Surplus sebesar $\pm 20.000 \mathrm{~m}^{3}$ perharitersebut meluap dan menggenangi daerah di sekitar pusat semburan lumpur sehingga perlu dibangun tanggul penahan lumpur yang mengelilingi pusat semburan Lumpur Sidoarjo.

Di sisi lain, jika ditinjau secara mineralogi, baik endapan lumpur maupun batulempung memiliki kandungan mineral lempung utama yang hampir sama yaitu: mineral kaolinit, illit, smektit dan klorit. Kelompok mineral tersebut dapat diidentifikasi baik karakteristik maupun komposisi kimia utamanya menggunakan sinar $\mathrm{X}$ yaitu dengan metode $\mathrm{X}$-Ray Diffraction (XRD) serta X-Ray Fluorescence (XRF).Penentuan komposisi mineral dan unsur kimia utama dari endapan lumpur dengan metode XRD dan XRF ini dapat diaplikasikan dalam identifikasi genesis serta karakteristik dari endapan lumpur yang berada di dalam tanggul Lumpur Sidoarjo.

Untuk itu perlu dilakukan penelitian untuk menganalisis kandungan mineral dan kimia dari endapan lumpur Sidoarjo sehingga dapat dimanfaatkan sesuai karakteristiknya. Sampel lumpur dinalisa menggunakan metode X-Ray Diffraction (XRD) dan X-Ray Fluorescence (XRF) untuk mengetahui mineralogi dan kandungan kimianya. Hasil identifikasi genesis dan karakteristik mineral lempung dari endapan Lumpur Sidoarjo dapat digunakan sebagai dasar pembuatan saran pemanfaatan surplus endapan Lumpur Sidoarjo.

Lokasi penelitian meliputi seluruh area tanggul penahan Lumpur Sidoarjo dengan luas \pm 640 ha dengan ketinggian dinding penahan tanggul setinggi 12 meter yang berada di Desa Renokenongo dan sekitarnya, Kecamatan Porong, Kabupaten Sidoarjo, Provinsi Jawa Timur.Secara fisiografis, Sidoarjo termasuk dalam Zona Depresi Kendeng yang merupakan kelanjutan dari Zona Bogor-Serayu Utara. Zona ini mengalami uplifting serta deformasi sejak Plio-Pleistosen yang mengakibatkan terbentuknya anticlinorium, yaitu puncak lipatan besar permukaan bumi yang tersusun atas beberapa puncak lipatan kecil (Satyana \& Asnidar, 2008).Fisiografis Sidoarjo dapat dilihat pada Gambar 1. Susunan stratigrafi daerah Sidoarjo dan sekitarnya dari tua ke muda adalah Formasi Ngimbang, Kujung, Prupuh, Kalibeng, Pucangan dan Endapan Aluvial.

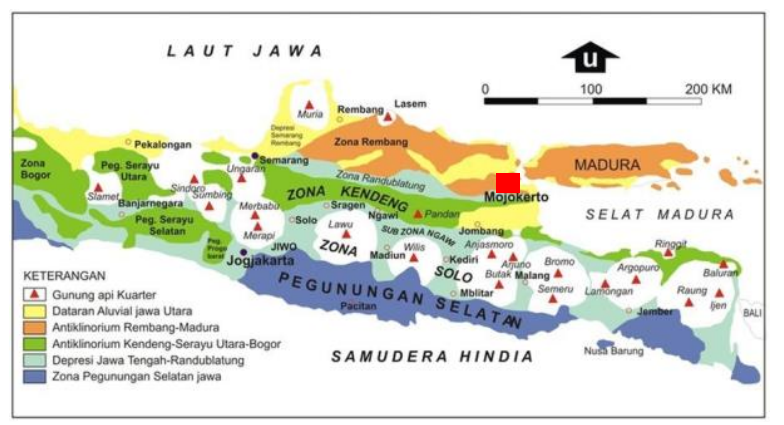

Gambar 1. Fisiografi Pulau Jawa Bagian Timur Menurut van Bemmelen (1970); Kotak merah merupakan daerah penelitian.

Daerah Porong memperlihatkan adanya struktur permukaan yang sudah lama dikenal dan disebut sebagai Sesar Watukosek. Pelurusan Zona Sesar Watukosek juga menunjukkan keberadaan gunungapi lumpur lain seperti gunungapi lumpur Penanggungan, Pulungan, Gunung Anyar dan Karang Anyar. Hal tersebut mengimplikasikan pengaruh Zona Sesar Watukosek terhadap sistem hidrotermal yang membentuk gunungapi lumpur di sepanjang daerah ini.Kondisi tektonik aktif serta endapan sedimen kaya material organik yang matang membuat Jawa Timur memiliki setting ideal untuk pembentukan gunungapi lumpur. Keberadaan sistem Sesar Watukosek yang berarah NE - SW di area Lumpur Sidoarjo memberikan saluran yang dibutuhkan oleh lumpur, fluida dan gas pada kedalaman permukaan untuk naik ke atas permukaan membentuk gunungapi Lumpur Sidoarjo (Istadi dkk, 2009). Lumpur Sidoarjo mulai muncul pada 5 titik berbeda yang tersebar di sepanjang zona Sesar Watukosek yang merupakan sesar geser sinistral yang memanjang dari kompleks pegunungan Arjuno-Welirang dimana zona sesar ini telah banyak menghasilkan erupsi lumpur prasejarah.

\section{Bahan dan Metode Penelitian}

Sampel lempung diambil langsung dari lapangan untuk dianalisis di laboratorium. Pemilihan lokasi pengambilan sampel ini didasarkan pada tingkat kesegaran sampel, kondisi sampel (basah dan kering) serta jarak titik sampel dengan pusat semburan..

\section{Analisis Sifat Fisik Lempung}

Analisis ini dilakukan untuk mengetahui sifat fisik endapan batuan seperti berat jenis, densitas, ukuran butir serta kadar air dari endapan lempung daerah penelitian. Analisis sifat fisik endapan lempung daerah penelitian ini dilakukan dalam dua tahap yaitu tahap pertama meliputi pengujian berat jenis dengan menggunakan analisis ASTM C128-93, densitas dengan menggunakan metode neraca pegas serta ukuran butir menggunakan metode analisis hidrometer. Tahap kedua pengujian yaitu analisis kadar air dengan menggunakan analisis ASTM C566-89 yang dilakukan oleh Pusat 


\section{TEKNIK, 40 (2), 2019, 93}

Pengendalian Lumpur Sidoarjo di laboratorium pengujian sifat fisik batuan.

\section{AnalisisX-Ray Diffraction (XRD)}

Tujuan dari analisis ini adalah untuk mengetahui mineral lempung (clay mineral) yang ada pada endapan lumpurpada lokasi semburan Lumpur Sidoarjo yang dianalisis lebih lanjutuntuk mengetahui genesa endapan lumpur tersebut. Uji XRD yang dilakukan pada ketiga sampel diberikan 2 macam perlakuan yaitu air dried serta etilen-glikol, pemberian perlakuan berbeda ini bertujuan untuk memperlihatkan mineral seperti montmorilonit yang menunjukkan kondisi berbeda saat diberikan kedua perlakuan ini. Analisis ini dilakukan oleh laboratorium geokimia, Departemen Teknik Geologi Universitas Gadjah Mada, Yogyakarta pada 3 (tiga) sampel lempung yang dianggap mewakili daerah penelitian.

\section{AnalisisX-Ray Fluorescence (XRF)}

Analisis XRF dilakukan pada sampel endapan lempung. Tujuan dari analisis ini adalah untuk mengetahui komposisi kimia dalam endapan lempung dalam bentuk presentase oksida utama sehingga dapat diketahui karakteristik dan genesis dari endapan lempung yang dianalisis. Analisis ini dilakukan oleh laboratorium geokimia Pusat Teknologi Bahan Galian Nuklir, Batan, Jakarta Selatan pada 3 (tiga) sampel yang dianggap mewakili daerah penelitian.

\section{Hasil dan Pembahasan}

Berikut merupakan pembahasan mengenai karakteristik Lumpur Sidoarjo, yang meliputi karakteristik fisik, karakteristik mineralogi dan karakteristik kimia.

\section{Karaketristik Fisik}

Karakteristik fisik endapan lempung daerah penelitian ditentukan dengan pengamatan lapangan pada sampel endapan lempung yang berada di dalam tanggul lumpur Sidoarjo serta pengujian laboratorium untuk mengetahui sifat fisik endapan. Secara fisik endapan lempung di lapangan memiliki warna abu-abu saat pada kondisi basah dan abu keputihan pada kondisi kering (Gambar 2.).

Berdasarkan analisisnya, karakteristik fisik endapan Lumpur Sidoarjo adalah memiliki nilai berat jenis yang besar yaitu antara 1,2 hingga 1,4 g/mL (Tabel 1) serta fraksi terbesar adalah lempung dengan persentase sebesar $81,5 \%$ (Tabel 2).
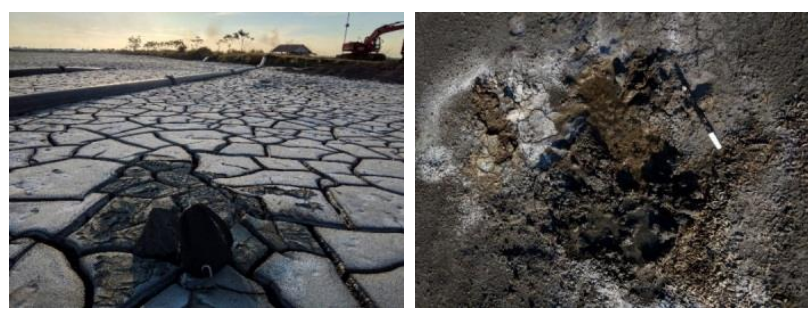

Gambar 2. Kondisi endapan lempung di lapangan

Tabel 1.Hasil uji laboratorium sifat fisik endapan Lumpur Sidoarjo (Pusat Pengendalian Lumpur Sidoarjo, 2007)

\begin{tabular}{cccc}
\hline \multirow{2}{*}{ Sampel } & \multicolumn{3}{c}{ Sifat Fisik } \\
\cline { 2 - 4 } & Volume $(\mathbf{m l})$ & Berat $(\mathbf{g})$ & Densitas $(\mathbf{g} / \mathbf{m L})$ \\
\hline LS-01 & 100 & 129,6 & 1,3 \\
LS-02 & 100 & 124,2 & 1,24 \\
LS-03 & 100 & 126,8 & 1,27 \\
LS-04 & 100 & 132,3 & 1,32 \\
LS-05 & 100 & 136,9 & 1,37 \\
LS-06 & 100 & 127,8 & 1,28 \\
LS-07 & 100 & 128,4 & 1,28 \\
LS-08 & 100 & 131,8 & 1,32 \\
LS-09 & 100 & 137,2 & 1,37 \\
LS-10 & 100 & 132,8 & 1,33 \\
LS-11 & 100 & 127,1 & 1,27 \\
LS-12 & 100 & 129,7 & 1,3 \\
LS-13 & 100 & 131,4 & 1,31 \\
LS-14 & 100 & 136,2 & 1,36 \\
LS-15 & 100 & 134,8 & 1,35 \\
\hline
\end{tabular}

Tabel 2Hasil pengujian ukuran butirendapan Lumpur Sidoarjo (Pusat Pengendalian Lumpur Sidoarjo, 2007)

\begin{tabular}{ccc}
\hline Jenis Butir & Satuan & Kandungan \\
\hline Gravel & $\%$ & 0 \\
Sand & $\%$ & 0,5 \\
Silt & $\%$ & 18 \\
Clay & $\%$ & 81,5 \\
\hline
\end{tabular}

\section{Karakteristik Mineralogi}

Dari 7 sampel yang diambil di lapangan sebanyak 3 sampel dilakukan pengujian laboratorium berupa analisis XRD guna mengetahui kompisisi mineral dari endapan lempung. Digunakan dua perlakuan berbeda pada masing masing sampel yang diuji XRD yaitu perlakuan air-dried(Gambar 3.a)dimana kondisi sampel diangin-anginkan pada udara terbuka sebelum dilakukan penembakan sinar XRD, perlakuan lainnya adalah sampel ditembak dengan sinar XRD setelah sebelumnya diberi larutan etilen-glikol(Gambar 


\section{TEKNIK, 40 (2), 2019, 94}

3.b). Tujuan dari dua perlakuan yang berbeda ini adalah untuk mengetahui mineral-mineral yang muncul pada kedua perlakuan serta mineral-mineral yang hanya muncul pada satu perlakuan saja. Metode pemberian larutan etilen-glikol digunakan untuk memisahkan serta mengidentifikasi mineral-mineral yang memiliki sifat non-swelling seperti illit dan klorit. Selain itu metode ini digunakan juga untuk memisahkan mineral smektit (montmorillonit) dengan mineral lempung mixed layers dikarenakan mineral mixed layers memiliki genesis yang berbeda dengan mineral smektit pada umumnya. Jenis mineral lempung tiap sampel dapat dilihat pada Tabel 3.

(a)

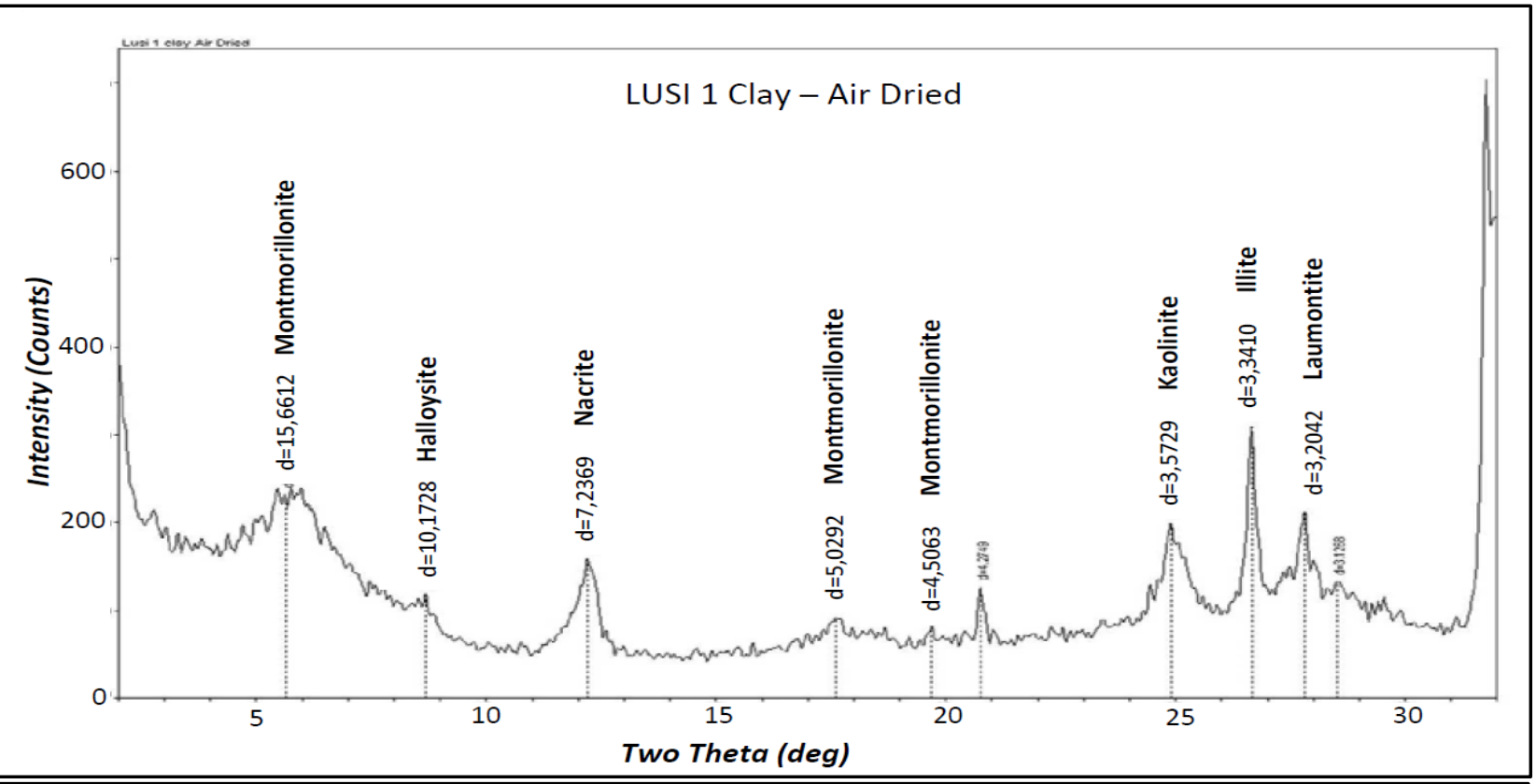

(b)

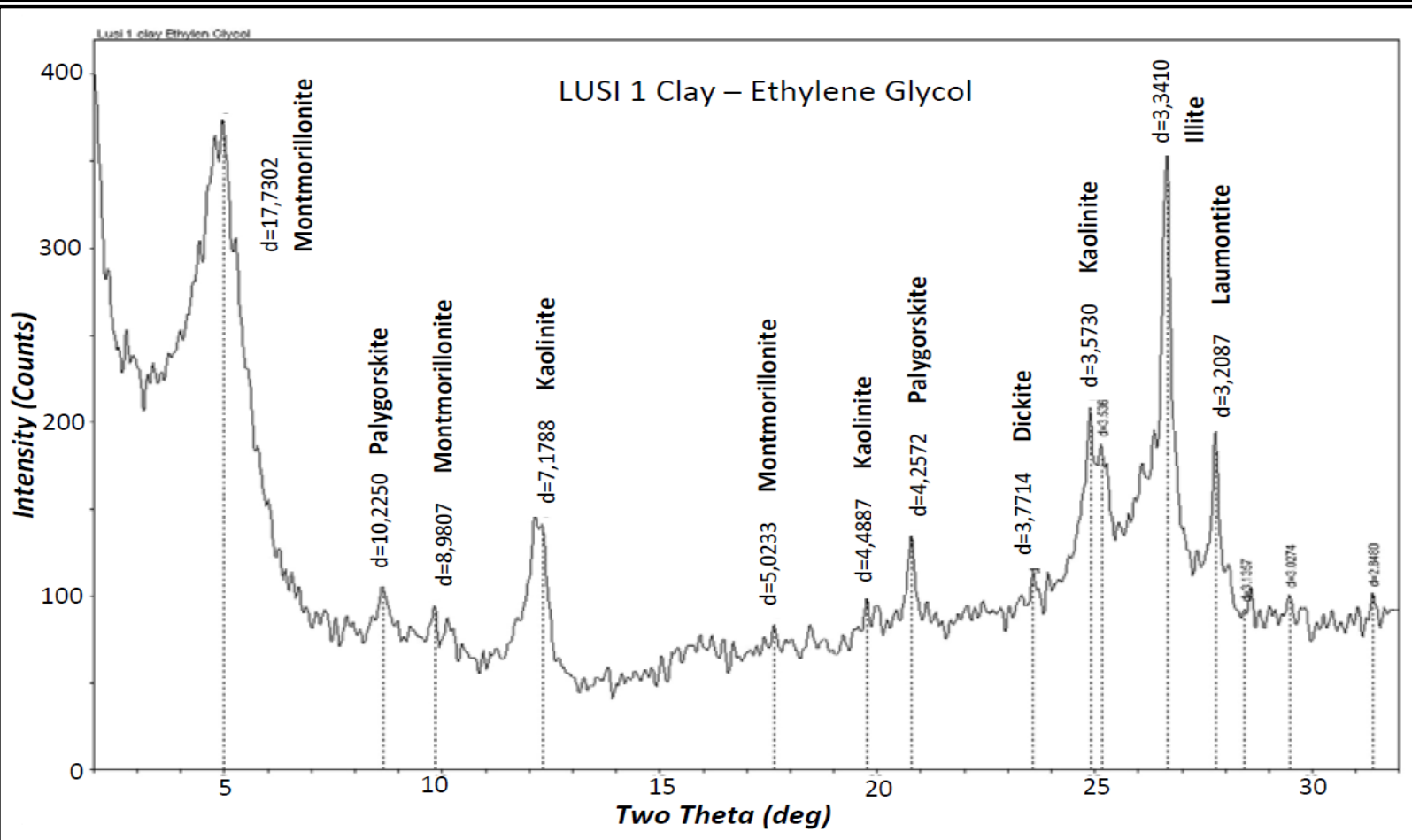

Gambar 3.Contoh grafik hasil analisis XRD menunjukkan puncak kemunculan mineral lempung tertentu, perbandingan perlakuan air dried (a) dan etilen glikol (b) pada sampel Lusi 1. 


\section{TEKNIK, 40 (2), 2019, 95}

Tabel 3. Hasil analisis XRD pada sampel endapan Lumpur Sidoarjo

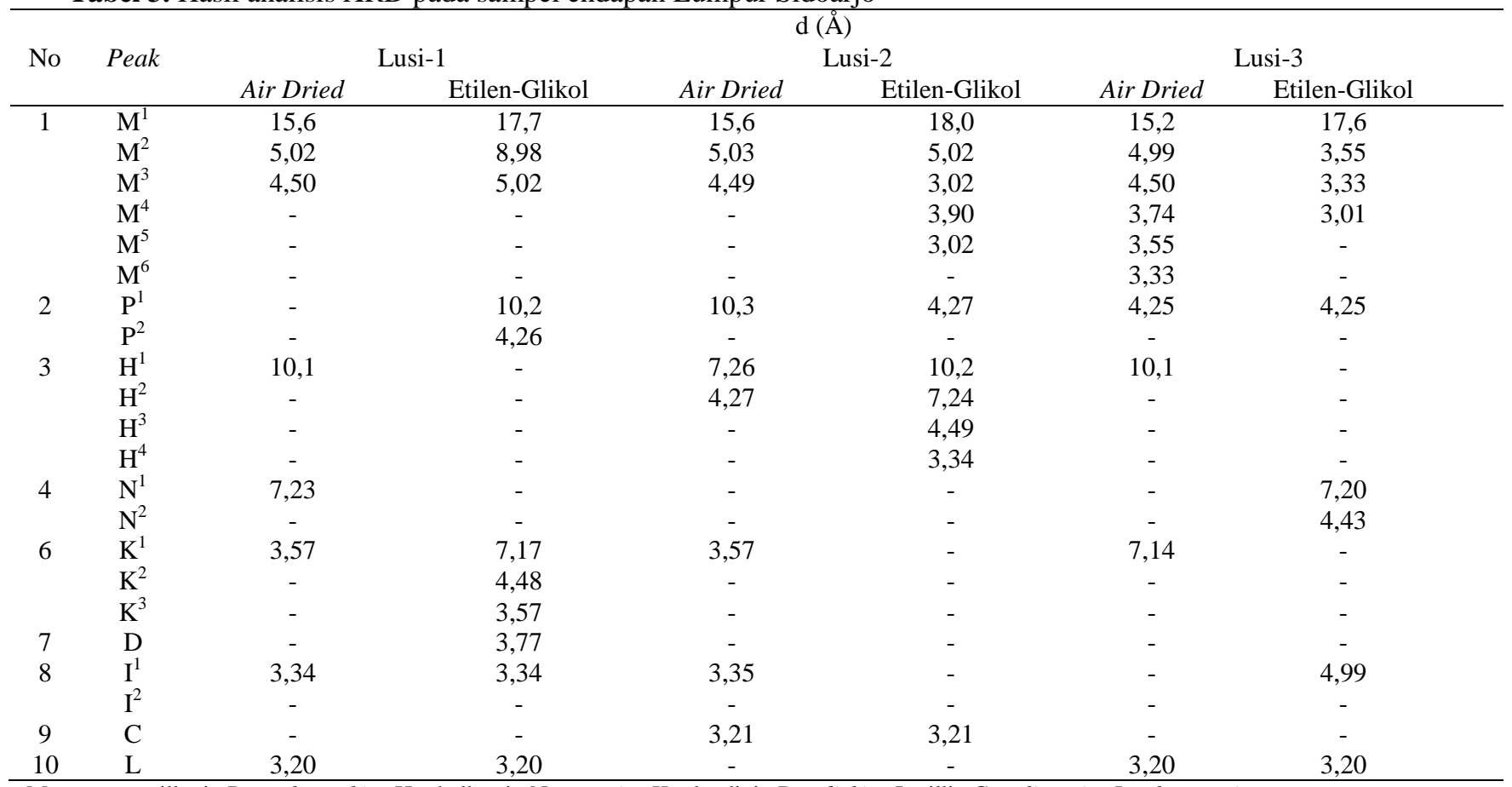

$\mathrm{M}=$ montmorillonit, $\mathrm{P}=$ palygorskite, $\mathrm{H}=$ halloysit, $\mathrm{N}=$ nacrite, $\mathrm{K}=$ kaolinit, $\mathrm{D}=$ dickite $, \mathrm{I}=\mathrm{illit}, \mathrm{C}=$ clintonite, $\mathrm{L}=$ laumontite

Hasil analisis XRD menunjukkan bahwa pada ketiga sampel dijumpai mineral mineral lempung seperti montmorillonit, halloysite, dan kaolinit, dalam jumlah yang relatif tinggi karena mineral mineral tersebut muncul lebih dari satu peaks serta intensitas yang cukup tinggi/tajam, selain itu juga dijumpai mineral dari kelompok illit namun dalam jumlah yang relatif sedikit. Selain mineral-mineral lempung utama tersebut juga ditemukan mineral lempung lain seperti palygorskite, nacrite, dickite, clintonite dan laumontite.

\section{Karakteristik Kimia}

Pengujian laboratorium lain yang dilakukan berupa analisis XRF guna mengetahui kelimpahan dari masing-masing oksida utamaserta trace elements dari endapan Lumpur Sidoarjo. Hasil analisis terlihat pada Tabel 4.

Genesis Endapan Lumpur Sidoarjo: Berdasarkan data XRD dan XRF dapat dibuat suatu interpretasi mengenai pembentukan endapan Lumpur Sidoarjo dimulai dari interpretasi batuan asal pembentuk endapan hingga proses geologi yang mengakibatkan naiknya endapan Lumpur Sidoarjo ke atas permukaan tanah. Apabila dikorelasikan dengan data XRF dari penelitian, mineral montmorillonit merupakan mineral yang paling dominan muncul. Berdasarkan komposisi sodium dan kalsiumnya dimana komposisi sodium memiliki presentase yang lebih tinggi, diinterpretasikan bahwa montmorillonit yang dijumpai pada daerah penelitian merupakan jenis NaMontmorillonit. Montmorillonit jenis tersebut merupakan jenis yang memiliki kemampuan untuk kembang-susut (swelling).

Tabel 4. Hasil analisis XRF sampel Lumpur Sidoarjo

\begin{tabular}{cccccc}
\hline \multirow{2}{*}{ No. } & \multirow{2}{*}{ Simbol } & \multicolumn{4}{c}{ Konsentrasi \% } \\
& Lusi-1 & Lusi-2 & Lusi-3 & Rata-rata \\
\hline 1 & $\mathrm{Na}_{2} \mathrm{O}$ & 5,91 & 3,76 & 3,20 & 4,29 \\
2 & $\mathrm{MgO}$ & 3,22 & 3,06 & 3,12 & 3,14 \\
3 & $\mathrm{Al}_{2} \mathrm{O}_{3}$ & 21,9 & 21,4 & 22,4 & 21,9 \\
4 & $\mathrm{SiO}_{2}$ & 54,7 & 57,0 & 58,4 & 56,7 \\
5 & $\mathrm{P}_{2} \mathrm{O}_{5}$ & 0,18 & 0,18 & 0,21 & 0,19 \\
6 & $\mathrm{~K}_{2} \mathrm{O}$ & 1,50 & 1,48 & 1,48 & 1,49 \\
7 & $\mathrm{CaO}$ & 2,15 & 3,23 & 2,64 & 2,67 \\
8 & $\mathrm{TiO}_{2}$ & 0,77 & 0,78 & 0,79 & 0,78 \\
9 & $\mathrm{Fe}_{2} \mathrm{O}_{3}$ & 6,58 & 7,00 & 7,32 & 6,96 \\
\hline Total & & 96.9 & 97.9 & 99.7 & \\
\hline
\end{tabular}

Kemunculan beberapa mineral lempung jarang turut mempengaruhi kondisi lingkungan tempat terbentuknya endapan Lumpur Sidoarjo. Ross dan Kerrmenyatakan bahwa mineral nacrite hanya dapat terbentuk pada lingkungan temperatur tinggi (Kerr, 1952). Keberadaan mineral palygorskite menunjukkan bahwa endapan Lumpur Sidoarjo 


\section{TEKNIK, 40 (2), 2019, 96}

memiliki hubungan dengan parent rock yang bersifat karbonatan ataupun berasal dari endapan lacustrine (Shadfan \& Dixon, 1984). Keberadaan mineral dickite yang keberadaanya sering dijumpai bersamaan dengan mineral kaolinit, mengindikasikan keterdapatan suatu urat hidrotermal di bawah permukaan lapangan Lumpur Sidoarjo.

Kondisi serta batasan batuan asal dari mineralmineral lempung dan non lempung di atas dapat dirangkum menjadi beberapa poin penting yaitu: 1) batuan asal dari endapan Lumpur Sidoarjo berasal dari batuan vulkaniklastik yang terendapkan pada lingkungan laut serta beraosisasi dengan batuan karbonatan. 2) Pembentukan endapan Lumpur Sidoarjo sangat dipengaruhi oleh aktivitas hidrotermal dengan suhu kurang dari $300{ }^{\circ} \mathrm{C}$. Sebelum dilakukan interpretasi batuan asal endapan Lumpur Sidoarjo terlebih dahulu perlu dipahami mengenai kondisi regional lokasi semburan Lumpur Sidoarjo yang merupakan bagian dari Cekungan Jawa Timur yang adalah inverted extensional basin (Matthews \& Bransden, 1995), dimana cekungan ini terdiri dari kumpulan graben berarah timur-barat yang aktif pada Paleogen dan mengalami pengaktifan kembali pada Miosen awal hingga Resen. Cekungan yang terbentuk pada Oligo-Miosen hingga Resen mengalami pengisian oleh material karbonat laut dangkal serta endapan lempung laut yang mana sebagian dari material tersebut diketahui sebagai material overpressured(Davies dkk., 2007). Keberadaan Kompleks Gunungapi Arjuno Welirang yang terdiri dari Gunungapi Arjuno, Gunungapi Welirang, Gunungapi Kawi dan Gunungapi Butak diinterpretasikan menjadi sumber panas dari sistem hidrotermal Lumpur Sidoarjo. Hipotesis tersebut juga didukung oleh penelitian geokimia gas pada pusat semburan Lumpur Sidoarjo yang dilakukan oleh (Mazzini $d k k ., 2007$ ) yang menunjukkan bahwa karakteristik geokimia gas pada pusat semburan hampir sama dengan karakteristik manifestasi kompleks gunungapi Arjuno-Welirang maupun gunungapi lumpur lain yang dijumpai di sekitar daerah penelitian.

Berdasarkan data tersebut diinterpretasikan bahwa sumber endapan Lumpur Sidoarjo berasal dari Formasi Kalibeng bagian atas yang mana penyusun formasi ini merupakan perselingan batupasir, tufa, tufaan, lapili tufa serta breksi yang memiliki lingkungan pengendapan laut dalam sehingga membentuk mekanisme pengendapan turbidit. Penyusun utama dari formasi ini merupakan batuan vulkanik sehingga memungkinkan terbentuknya mineral montmorillonit yang dijumpai pada endapan Lumpur Sidoarjo sebagai mineral dominan. Keberadaan mineral-mineral lempung jarang lain diinterpretasikan merupakan pengaruh dari naiknya fluida hidrotermal.

\section{Arahan Pemanfaatan Endapan Lumpur Sidoarjo}

Endapan lempung merupakan salah satu material yang umum digunakan dalam berbagai bidang seperti pertanian, perikanan, kesehatan dan industri. Pemanfaatan endapan lempung khususnya Lumpur Sidoarjo selain untuk mengurangi surplus endapan yang dihasilkan pada lokasi tanggul setiap harinya juga dikarenakan endapan lempung secara mineralogi, sifat fisik dan geokimianya merupakan natural absorbent yang baik.

\section{Pemanfaatan endapan Lumpur Sidoarjo dalam bidang kesehatan}

Pemanfaatan mineral lempung dalam bidang kesehatan khususnya pembuatan obat-obatan melibatkan mineral-mineral lempung seperti smektit, palygorskite dan kaolinit. Mineral-mineral tersebut dapat digunakan sebagai konstituen aktif atau eksipien. Mineral lempung memiliki sifat-sifat seperti area permukaan luas, kapasitas sebagai adsorben, sifat reologi, sifat inert mineral terhadap reaksi kimia dan tingkat kadar racun yang rendah atau bahkan tidak ada bagi pasien (Carretero, 2002).Penggunaan mineral lempung sebagai konsituen aktif dapat diaplikasikan baik secara oral maupun topical. Pengunaan mineral lempung secara oral meliputi: (1) Pelindung gastrointestinal, (2) Obat pencahar oral, 3) Antidiare. Pengunaan mineral lempung secara topical meliputi: (1) Pelindung kulit, (2) Bahan eksipien.Selain digunakan sebagai sistem transportasi bahan gizi, mineral lempung khususnya montmorillonit juga telah banyak digunakan sebagai salah satu bahan campuran yang digunakan dalam pembuatan rekayasa jaringan tulang.

\section{Pemanfaatan endapan Lumpur Sidoarjo dalam bidang pertanian}

Percobaan yang dilakukan (Shattar, Zakaria, \& Foo, 2017) menunjukkan bahwa mineral montmorillonit merupakan bahan yang baik digunakan dalam perawatan polusi herbisida sekunder yang dapat secara langsung diaplikasikan di lapangan baik pada endapan tanah maupun tubuh air.

\section{Pemanfaatan endapan Lumpur Sidoarjo dalam bidang perikanan.}

Pemanfaatan mineral lempung di bidang perikanan didasarkan pada kemampuan mineral lempung sebagai adsorben alami dimana struktur berlapis dari mineral lempung memiliki kemampuan untuk mengembang (swelling) ketika mengalami kontak dengan air sehingga dapat digunakan untuk menyerap bahan-bahan kimia berbahaya seperti 


\section{TEKNIK, 40 (2), 2019, 97}

ammonia di dalam air (Rozic dkk, 2000 dalam Ismadji $d k k .$, 2015).

\section{Pemanfaatan endapan Lumpur Sidoarjo dalam bidang industri}

Pemanfaatan mineral lempung pada bidang industri umumnya menggunakan mineral kaolinit sebagai bahan dasar dalam industri keramik, cat, plastik dan karet (Murray, 1961)

Mineral kaolin banyak digunakan dalam industri karet sebagai bahan tambahan. Penambahan mineral kaolin dapat memberikan peningkatan kekuatan, resistensi terhadap kerusakan dan kekakuan. Alasan utama penggunaan kaolin dalam industri karet adalah biaya yang lebih murah serta memberikan sifat fungsional yang baik. Mineral kaolin juga digunakan sebagai bahan pembuat cat karena mineral ini secara kimia tidak dapat bereaksi ataupun larut dalam cat, dapat memberikan sifat flow pada cat serta biaya yang murah. Penambahan mineral kaolin dalam material thermosetting dan thermoplastic memberikan sifat permukaan yang halus, finishing produk yang lebih baik serta memberikan resistensi terhadap serangan bahanbahan kimia. Penambahan kaolin juga dapat memberikan kemudahan dalam pembentukan bentuk dasar suatu plastik.

\section{Pemanfaatan endapan Lumpur Sidoarjo dalam bidang kosmetik \\ Pada endapan Lumpur Sidoarjo kelompok} mineral yang ditemukan yang dapat digunakan pada bidang kosmetik adalah kaolin serta montmorillonit. Kelompok mineral kaolin digunakan dalam produkproduk seperti pelindung kulit, krim kosmetik serta bedak sedangkan montmorillonit digunakan dalam produk-produk seperti pelindung kulit, krim kosmetik, bedak serta masker (Carretero \& Pozzo, 2009).

Pengunaan mineral lempung sebagai produk kosmetik ini memiliki suatu parameter dimana kandungan kimia pada mineral lempung harus berada di dalam range agar dapat diproduksi sebagai produk kosmetik, adapun perbandingan spesifikasi mineral lempung dalam bidang farmasi dan kosmetik (LopezGalindo, Viseras \& Cerezo, 2007) dengan kadar mineral lempung daerah penelitian dapat dilihat pada Tabel 5. Mineral montmorillonit pada ketiga titik sampel memenuhi syarat untuk digunakan sebagai bahan baku produk kosmetik.

\section{Kesimpulan}

Hasil analisis menunjukkan bahwa endapan lempung dari semburan lumpur Sidoarjo di Kecamatan Porong memiliki berat jenis $1,2-1,3$ $\mathrm{g} / \mathrm{mL}$, ukuran butir didominasi oleh clay dengan komposisi sebesar 81,5\% dan kadar air sebesar 30 $40 \%$. Berdasarkan analisis X-Ray Diffraction (XRD)endapan lempung memiliki kandungan mineral lempung yang dominan adalah montmorillonit, halloysit, dan kaolinit. Hasil analisis XRF mendukung hasil dari analisis XRD. Berdasarkan kandungan dominan monmorilonit, dapat dinterpretasikan bahwa genesis mineral lempung berasal dari ubahan batuan vulkanikdari Formasi Kalibeng bagian atas. Penyusun formasi ini merupakan perselingan batupasir, tufa, tufaan, lapili tufa serta breksi yang memiliki lingkungan pengendapan laut dalam. Endapanlempung pada daerah penelitian dapat dimanfaatkan dalam bidang kesehatan, pertanian, perikanan, industry, dan kosmetik, Sebelumnya, harus dilakukan pemisahan partikel mineral lempung dengan mineral non lempung serta zat pengotor pada endapan Lumpur Sidoarjo. Selainitu perlu dikaji lebih lanjut aplikasi mineral lempung daerah penelitian pada berbagai bidang industri menggunakan saran dan spesifikasi yang telah dibahas.

Tabel 5.Perbandingan spesifikasi mineral lempung dalam bidang farmasi dan kosmetik (LopezGalindoViseras \& Cerezo, 2007) dengan kadar mineral lempung daerah penelitian

\begin{tabular}{|c|c|c|c|c|c|}
\hline \multirow[b]{2}{*}{ No } & \multirow[b]{2}{*}{ Simbol } & \multirow{2}{*}{$\begin{array}{c}\% \\
\text { Montmorillonite }\end{array}$} & \multicolumn{3}{|c|}{ Konsentrasi \% } \\
\hline & & & $\begin{array}{c}\text { Lusi- } \\
1\end{array}$ & $\begin{array}{l}\text { Lusi- } \\
2\end{array}$ & $\begin{array}{c}\text { Lusi- } \\
3\end{array}$ \\
\hline 1 & $\begin{array}{c}\mathrm{Na}_{2} \\
\mathrm{O}\end{array}$ & $0-3,7$ & 5.91 & 3.76 & 3.20 \\
\hline 2 & $\mathrm{MgO}$ & $0,1-7,4$ & 3,22 & 3,06 & 3,12 \\
\hline 3 & $\mathrm{Al}_{2} \mathrm{O}$ & $15,2-34$ & 21,9 & 21,4 & 22,4 \\
\hline 4 & $\mathrm{SiO}_{2}$ & $51,2-65$ & 54,7 & 57,0 & 58,4 \\
\hline 6 & $\mathrm{~K}_{2} \mathrm{O}$ & $0-1,8$ & 1,50 & 1,48 & 1,48 \\
\hline 7 & $\mathrm{CaO}$ & $0-4,2$ & 2,15 & 3,23 & 2,649 \\
\hline 8 & $\begin{array}{l}\mathrm{TiO}_{2} \\
\mathrm{Fe}_{2} \mathrm{O}\end{array}$ & $0-2,9$ & 0,77 & 0,78 & 0,80 \\
\hline 9 & 3 & $0-13,6$ & 6,58 & 7,00 & 7,32 \\
\hline
\end{tabular}

\section{Ucapan Terima Kasih}

Terima kasih disampaikan kepada Anton Winarto dan Alwi Husein selaku pembimbing lapangan selama melakukan kegiatan pengambilan data penelitian di Pusat Pengendalian Lumpur Sidoarjo.

\section{Daftar Pustaka}

Carretero, M. I. (2002). Clay Minerals and Their Beneficial Effects upon Human Health. A 


\section{TEKNIK, 40 (2), 2019, 98}

Review. Applied Clay Science, 21(3-4), 155163.

Carretero, M.I., Pozo, M. (2009). Clay and non-clay minerals in the pharmaceutical industry Part I. Excipients and medical applications. Applied Clay Science, 46(1), 73-80.

Davies, R. J., Swarbrick, R. E., Evans, R. J., Huuse, M. (2007). Birth of a Mud Volcano: East Java, 29 May 2006, United Kingdom: Centre for Research into Earth Energy.

Ismadji, S., Soetaredjo, F. E., Ayucitra, A. (2015). Natural Clay Minerals as Environmental Cleaning Agents. Clay Materials for Environmental Remediation, 5-37.

Istadi, B.P., Pramono, G.H., Sumintadireja, P., Alam, S. (2009).Modeling study of growth and potential geohazard for LUSI mud volcano:East Java, Indonesia.Marine and Petroleum Geology, 26(9), 1724-1739.

Kerr, P. F. (1952). Formation and Occurrence of Clay Minerals. Clays and Clay Minerals, 1(1), 1932.

Lopez-Galindo, A., Viseras, C., Cerezo, P. (2007). Compositional, Technical and Safety Specifications of Clays to be used as Pharmaceutical and Cosmetic Products.: Applied Science, 36(1-3), 51-63.

Matthews, S. J., Bransden, P. J. E. (1995). Late Cretaceous and Cenozoic TectonoStratigraphic Development of the East Java Sea Basin, Indonesia. Marine and Petroleum Geology, 12(5), 499-510.
Murray, H. (1961). Industrial Applications of Kaolin New Jersey: Georgia Kaolin Company.

Mazzini, A., Svensen, H., Akhmanov, G.G., Aloisi, G., Planke, S., Malthe-Sørenssen, A., Istadi, B. (2007). Triggering and dynamic evolution of the LUSI mud volcano, Indonesia,Earth and Planetary Science Letters, 261(3-4), 375388.

Pusat Pengendalian Lumpur Sidoarjo. (2007). Laporan Penelitian Sifat Lumpur. Surabaya: Pusat Pengendalian Lumpur Sidoarjo.

Satyana, A.H., Asnidar. (2008). International Petroleum Association Annual Meeting. Mud Diapirs and Mud Volcanoes in Depressions of Java to Madura: Origins, Natures, and Implications to Petroleum System. Indonesia: Indonesian Petroleum Association.

Shadfan, H., Dixon, J. B. (1984). Occurance of Palygorskite in the Soils and Rocks of the Jordan Valley. Developments in Sedimentology, 37, 187-198.

Shattar, S. F. A., Zakaria, N. A., Foo, K. Y. (2017). Utilization of Montmorillonite as A Refining Solution for Treatment of Ametryn, A Second Generation of Pesticide. Journal of Environmental Chemical Engineering, 5(4), 3235-3242.

van Bemmelen, R.W., (1970).The Geology of Indonesia, IA. The Hague: Government Printing Office. 